\title{
Abrasive wear in wear plates and hard coatings applied by welding with shielded electrode
}

\author{
Desgaste abrasivo en láminas antidesgaste y recubrimientos duros \\ aplicados por soldadura con electrodo revestido
}

Desgaste abrasivo em lâminas antidesgaste e recobrimentos duros aplicados por soldadura com eletrodo revestido

Fecha de recepción: 21 de abril de 2017

Fecha de aceptación: 22 de agosto de 2017

José Luddey Marulanda-Arévalo*

Luz Adriana Cañas-Mendoza** Jairo Alberto Barón-Jaimez

\section{Abstract}

Performance against abrasive wear was evaluated (in compliance with the ASTM G-65 standard) for both wear plates and hard coatings applied by electric welding. The characterization of the coatings was achieved by using hardness tests, optical microscopy and scanning electron microscopy (SEM). Although it was observed a direct correlation between hardness and wear resistance, a linear growth pattern was not followed. Besides the information from the hardness tests, data regarding the distribution and shape of the carbides in the welding bead are also necessary to choose the hard coating applied by welding, to protect against abrasive wear. Base metal and coatings had satisfactory joint, due to their dilution; the first welding layer had less hardness than the third welding layer.

Keywords: Abrasion, Coating, Plates, SMAW, Tribology, Wear, Weld.

\section{Resumen}

Se evaluó el desempeño frente al desgaste abrasivo de láminas antidesgaste y recubrimientos duros aplicados por soldadura eléctrica, utilizando la norma ASTM G-65. Para caracterizar los recubrimientos, a algunos depósitos se les hicieron pruebas de dureza, microscopia óptica y microscopia electrónica de barrido (SEM). Se observó que a medida que aumenta la dureza, aumenta la resistencia al desgaste, pero también se evidenció que no se sigue un patrón de crecimiento lineal. Por lo tanto, la dureza es información que nos puede dar un criterio de selección, pero no puede ser el único factor a la hora de elegir un recubrimiento duro aplicado por soldadura para la protección contra el desgaste abrasivo, ya que hay otros factores que afectan el desgaste, como la distribución y forma de los carburos en el cordón de soldadura. La unión de los recubrimientos con el metal base es muy buena. La dilución con el metal base hace que la dureza del primer pase de soldadura sea menor que la del tercer pase.

Palabras clave: Abrasión, Desgaste, Láminas, Revestimiento, Soldadura, SMAW, Tribología.

* Ph. D. Universidad Tecnológica de Pereira (Pereira-Risaralda, Colombia). jlmarulanda@utp.edu.co. ORCID: 0000-0002-2607-3625.

** M. Sc. Universidad Tecnológica de Pereira (Pereira-Risaralda, Colombia). luzadriana@utp.edu.co.

*** M. Sc. Universidad Nacional Autónoma de México (Ciudad de México, México). 


\section{Resumo}

Avaliou-se o desempenho perante o desgaste abrasivo de lâminas antidesgaste e recobrimentos duros aplicados por soldadura elétrica, utilizando a norma ASTM G-65. Para caracterizar os recobrimentos, a alguns depósitos foram feitas provas de dureza, microscopia ótica e microscopia eletrônica de varredura (SEM). Observou-se que a medida que aumenta a dureza, aumenta a resistência ao desgaste, mas também evidenciou-se que não se segue um padrão de crescimento linear. Portanto, a dureza é a informação que nos pode dar um critério de seleção, mas não pode ser o único fator à hora de escolher-se um recobrimento duro aplicado por soldadura para a proteção contra o desgaste abrasivo, já que há outros fatores que afetam o desgaste, como a distribuição e a forma dos carbonetos no cordão de soldadura. A união dos recobrimentos com o metal base é muito boa. A diluição com o metal base faz que a dureza do primeiro passe de soldadura seja menor que a do terceiro passe.

Palavras chave: Abrasão, Desgaste, Lâminas, Revestimento, Soldadura, SMAW, Tribologia. 


\section{INTRODUCTION}

Corrosion, wear and fracture, especially on the surface of materials, are considered the main issues in devices and machinery used in mining, metallurgy, mechanical, oil, and civil engineering. This failure in the materials not only leads to high economics losses, but also human losses. The manufacturing of wear plates and hard coatings resistant to wear has improved the quality of the machinery; additionally, these protective techniques contribute to develop maintenance and production technology [1]. Wear consists in loss of material and dimension decrease, hence tolerances loss. In general, wear affects the useful life and reliability of almost all machines [2]. Predicting wear is difficult because it is not an intrinsic property of the material, but it depends on tribosystems in which the bodies interact [3].

In industries such as agriculture, mining, and oil, working conditions create a difficult environment to steels, wear plates, and protective coatings, due to processing, transportation or removal of the large amount of highly abrasive stones and sand, which may induce damages such as severe abrasion and wear by impact. Wear plates and hard coatings may extend the useful life of machinery by increasing wear resistance $[4,5]$. In many cases, an increase in the material's hardness entails better abrasive wear resistance; this correlation takes place when the presence of carbides is neglected. Other variables that affect abrasive wear resistance are carbides morphology, matrix nature, and mechanisms of material elimination [6, 7]. Hard coatings and maintenance welding allow better and longer performances and fewer failures. Hard coatings applied to industrial maintenance enable immediate availability of parts and lower repair costs; thus, the operation of critic systems is guaranteed, and the purchase of parts may decrease $[8,9]$.

In order to select the appropriate wear plate or protective coating, it is necessary to know the forms and conditions of wear, because they can change the level of resistance and performance [10]. Prior to the application of the protective coating, it is necessary to remove fatigued material, dirt, grease, oils, oxides, as well as contaminants from the surface of the welding zone; also, the weldability must be analyzed to ensure a good welding procedure [11]. This study compares the behavior against abrasive wear of two kinds of samples: wear plates and two different hard coatings (iron-chromium and tungsten carbide). The former coating has been reported to have lower cost and acceptable performance. Coatings were applied by SMAW welding $[4,5,12]$.

\section{EXPERIMENTAL PROCEDURES}

Two types of $76 \mathrm{~mm} \times 25 \mathrm{~mm} \times 9 \mathrm{~mm}$ specimens of wear plates were prepared in accordance with the ASTM G65 standard. While one group of samples was coated with ASTM A36 steel, the other group was hardened by quenching treatment. Two kinds of hard coatings were applied. On one hand, CDP 4666 wear plates were coated with a material made of a matrix with high content of chromium and presence of chromium, niobium and boron carbides. On the other hand, CDP 6503 wear plates were protected with a material made of a nickel matrix and presence of tungsten carbides. The nanostructured plates had a similar composition to the CDP 4666 plate.

AISI 1045 steel was selected as the metal base for welding coated samples. Their dimensions were the same as those of the wear plates. The specimens were subjected to shot blasting to remove oil, oxides and other contaminants from the surfaces. Subsequently, hard coatings were applied by Shielded Metal Arc welding (SMAW). Three welding beads at flat position were deposited, obtaining one or three layers of hard coating. A REGAS 350 equipment was used with deposition current range of $90 \mathrm{~A}-140 \mathrm{~A}$, for $1 / 8$ in electrodes applied with Direct Current Electrode Positive (DCEP) and welding speed of $4 \mathrm{in} / \mathrm{s}-6 \mathrm{in} / \mathrm{s}$ (manufacturer's recommendation). The percentages of the alloy elements in weld layers varied, being changes of carbon (from $0.2 \%$ to $0.85 \%$ ) and chromium (from $1 \%$ to $13 \%$ ) the most significant.

For the welding process no preheating was used, and special care was taken to maintain the amperage and the essential variables recommended by the manufacturer for the welding process. The first hard coating layer was approximately $2 \mathrm{~mm}$ thick. The coating of each specimen was made with short alternating cords, giving a cooling time between passes to avoid the heating of the specimen. After the welding process, the specimens were cooled in a calcium carbonate mixture $(96 \%$ $\mathrm{CaCO}_{3}$ and $4 \%$ other elements) to reduce the risk of cracking and warping; then, the specimens were passed through a polisher to obtain a flat surface, ensuring that the opposing faces of the specimen were parallel. 


\section{TABLE 1}

\section{CHEMICAL COMPOSITION AND MECHANICAL PROPERTIES OF ASTM A36 AND AISI 1045 STEELS}

\begin{tabular}{|c|c|c|c|c|c|c|c|c|}
\hline & $\% \mathrm{C}$ & $\begin{array}{c}\% \\
\mathrm{Mn}\end{array}$ & $\begin{array}{c}\% \mathrm{P} \\
\text { max. }\end{array}$ & $\begin{array}{c}\% \mathrm{~S} \\
\text { max. }\end{array}$ & $\begin{array}{c}\% \mathrm{Si} \\
\text { max. }\end{array}$ & $\begin{array}{c}\text { Yield } \\
\text { strength } \\
(\mathrm{MPa})\end{array}$ & $\begin{array}{c}\text { Ultimate } \\
\text { strength } \\
(\mathrm{MPa})\end{array}$ & $\begin{array}{c}\text { Elongation } \\
(\%)\end{array}$ \\
\hline ASTM A36 & 0.25 & 0.8 & 0.04 & 0.05 & 0.4 & 250 & 500 & 23 \\
\hline AISI 1045 & 0.46 & 0.8 & 0.04 & 0.05 & 0.4 & 413 & 655 & 20 \\
\hline
\end{tabular}

The abrasive wear tests were carried out on a rubber wheel and dry sand machine, constructed according to ASTM G65-04 and type B procedure, which require a force of $130 \mathrm{~N}$ and 2000 revolutions to generate a test distance of $1436 \mathrm{~m}$; each test took 10 minutes. The used sand had an AFS 50/70 granulometric size. The sand flow on the wear surfaces was approximately 310 $\mathrm{g} / \mathrm{min}$, verifying that the abrasive formed a uniform curtain (laminar flow). The machine built according to ASTM G-65 was used to know its properties against wear of the materials. Prior to the abrasion tests, the specimens were subjected to a sanding process with emery paper 600 and acetone to remove residues of grease or other contamination on the surface as a product of handling. At the end of each abrasion test, the specimens went through an acetone cleaning process. To determine the mass loss, mass data were taken before and after every test performed with a balance of $1 \times 10^{-5} \mathrm{~g}$ resolution. hardness in Rockwell C (HRC) was measured according to ASTM E18-08, with a diamond indenter and a load of $150 \mathrm{Kgf}$ for $10 \mathrm{~s}$, taking 5 measurements in each zone. Optical microscopy was also performed, and weld morphology was analyzed by scanning electron microscopy (SEM), with a Phenom Xpro, which has a thermoionic source (CeB6) and works with acceleration potentials up to $15 \mathrm{kV}$. The composition of the weld layers was studied by detecting dispersed energy (EDS).

\section{RESULTS AND DISCUSSION}

Table 2 shows the volume average losses of the coatings, where deviations up to $11 \%$ were found for coatings that suffered heavy losses, and $3 \%$ for coatings that had small losses. Table 2 also shows HRC for hard coatings (layers) and uncoated steel. Hardness was within the range specified by manufacturers. Layers 1A, 2A, 3A and 4A correspond to West Arc $350,450,550$ and 650 hard coatings; layers $1 \mathrm{~B}$ and $2 \mathrm{~B}$ correspond to Citodur 350 and 600 ; layers $1 \mathrm{C}$ and $2 \mathrm{C}$ correspond to Bolher 600 and 620; and layers 1D, 2D, 3D and 4D correspond to Eutectrode 2B, Eutectrode
40, Xuper 5005 and Abratec N 700. The wear plates were named as follows: Nano corresponds to the plate with nanostructured compound in the welding flux; CDP 4666, to 4666; CDP 6503 with titanium carbides, to titanium; and the wear plate with heat treatment, to abrazo 400 and CR400.

\section{TABLE 2}

RESULTS OF WEAR TESTS

\begin{tabular}{|c|c|c|}
\hline Specimens & Volume loss $\left(\mathbf{m m}^{\mathbf{3}}\right)$ & $\begin{array}{c}\text { Hardness } \\
\text { (HRc) }\end{array}$ \\
\hline AISI 1045 & 92.87 & 28.99 \\
Layer 1A & 81.54 & 36.04 \\
Layer 2A & 68.92 & 48.75 \\
Layer 3A & 66.45 & 52.94 \\
Layer 4A & 65.27 & 60.86 \\
Layer 1B & 81.04 & 33.08 \\
Layer 2B & 61.94 & 54.55 \\
Layer 1C & 75.41 & 38.58 \\
Layer 2C & 62.13 & 55.92 \\
Layer 1D & 81.03 & 33.82 \\
Layer 2D & 73.54 & 48.52 \\
Layer 3D & 30.82 & 57.67 \\
Layer 4D & 29.14 & 67.55 \\
\hline Nano & 9.92 & 65.36 \\
\hline 4666 & 16.93 & 62.13 \\
\hline Titanium & 20.57 & 52.36 \\
\hline Abrazo 400 & 55.80 & 39.96 \\
\hline CR 400 & 54.01 & 39.06 \\
\hline
\end{tabular}

The uncoated steel had the lowest hardness and the largest volume loss because it was not protected. However, the wear resistance with respect to layer coatings $1 \mathrm{~A}, 1 \mathrm{~B}$ and $1 \mathrm{D}$ was relatively small, since the weight loss decreased by approximately $13.9 \%$ with layer $1 \mathrm{~A}, 14.5 \%$ with layer $1 \mathrm{~B}$, and $14.6 \%$ with layer $1 \mathrm{D}$; therefore, the performance of these coatings was low. The layers $1 \mathrm{C}$ and 2D showed better protection, 
achieving a decrease in weight loss of $23.1 \%$ and 26.2 $\%$ respectively. The volume loss between coatings layer $4 \mathrm{~A}, 2 \mathrm{~B}$ and $2 \mathrm{C}$ was similar and no significant changes were noticed; these coatings improved the abrasive wear resistance between $42 \%$ and $50 \%$. The 3D and $4 \mathrm{D}$ coatings greatly increased hardness and decreased the volume loss, improving abrasive wear resistance by more than $300 \%$. In general, wear plates had an excellent abrasive wear performance; the nano wear plate improved its performance over $930 \%$ compared to 1045 uncoated steel, and over $340 \%$ compared to the best hard coatings applied by welding. The wear plates manufactured with coatings are better than the hard coatings applied with welding, since CDP 4666 improved their performance by more than $70 \%$, and the titanium plate by more than $40 \%$, compared to the best hard coating applied with welding. The wear plates hardened by quenching heat treatment (abrazo 400 and CR 400) had a better performance than almost all hard coatings, with the exception of $3 \mathrm{D}$ and $4 \mathrm{D}$ coatings that had the highest performance.

Figure 1 shows the hardness values in Rockwell $\mathrm{C}$ and the loss of volume $\left(\mathrm{mm}^{3}\right)$ of the different coatings and wear plates. An increase in wear resistance was observed as the hardness increased, but a linear growth pattern was not evident. Therefore, information on hardness can provide a selection criterion, but it is not the only determining factor when choosing a weld for protection against abrasive wear. Coatings that have chromium resisted abrasive wear better, since they formed chromium carbides that are more resistant than the iron carbides; in addition, the more complex the chromium carbide and the better the morphological distribution of these carbides, the better the behavior against abrasive wear. The precipitation of carbides in steel depends on the amount of chromium and carbon; when the ratio is lower than $3: 1$, the formed carbide is cementite alloyed, but if the ratio is higher than $3: 1$, chromium carbides are formed as $\mathrm{Cr}_{7} \mathrm{C}_{3}$ and $\mathrm{Cr}_{23} \mathrm{C}_{6}$ [6]. Thus, a hardness test cannot fully evaluate the behavior against abrasive wear, since the relationship between microstructure and wear is very complex and is not fully understood. The development of Fe$\mathrm{Cr}-\mathrm{C}$ coating seeks to obtain good wear resistance with materials having a high-volume content of hard phases, which rely on a matrix with good toughness, since the difference in hardness between the matrix and the carbides affect the wear surface [5, 12]. Wear plate manufactured with coatings had less or similar hardness than the high-performance hard coatings applied by welding, yet their resistance to abrasive wear was higher because they have niobium, chromium, molybdenum and cobalt carbides, which are more resistant to this kind of wear.

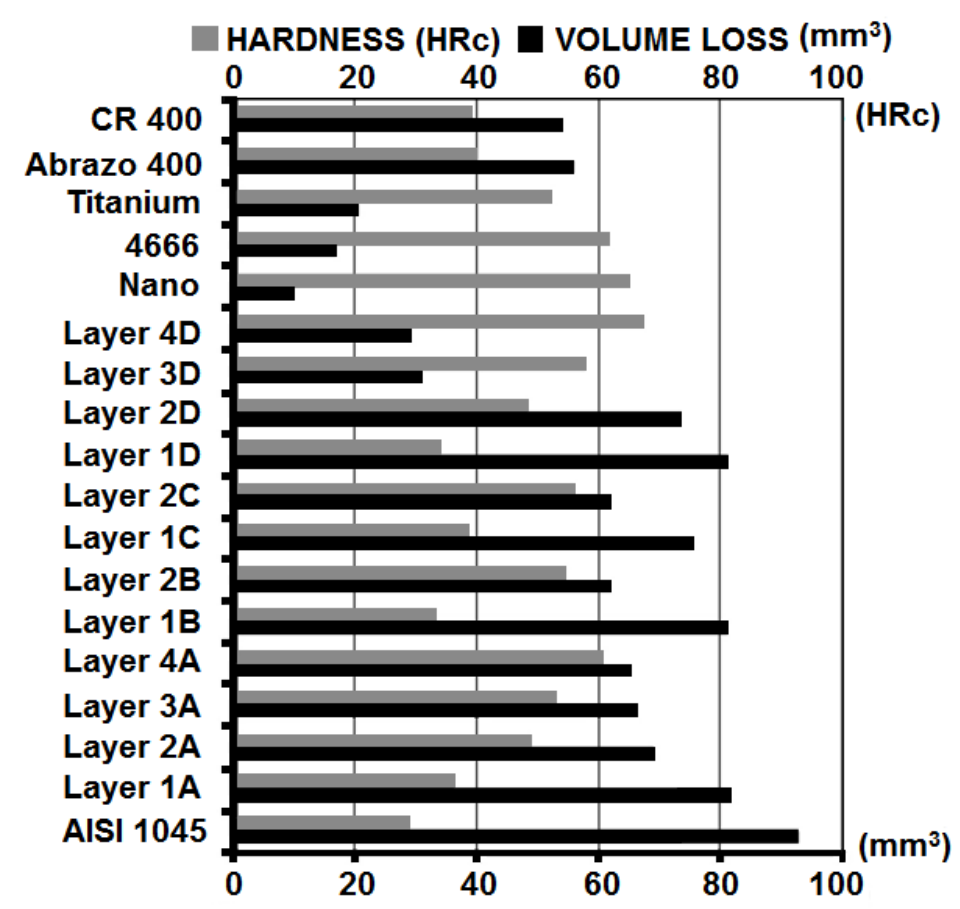

Fig. 1. Volume loss and hardness of wear plate and hard coatings. 
Figure 2 compares the average hardness and volume loss for hard coating in first and third layers, since manufacturers claim that the best performance is achieved in the third layers. Moreover, third layers have greater hardness than the first layers, due to less dilution of metal base. Thus, third layers also report less volume loss in comparison to the first ones $(5 \%$ $11 \%)$. In order to avoid a decrease in the mechanical properties of hard coatings, there should be little metal base in the welding bead, hence only a small transition zone would be created. Figure 2 also shows that dilution affected the hardness of the first layers with a slight reduction of their abrasive wear resistance.

Manufacturers recommend a maximum of two welding layers of the coating with greater hardness (4A and $4 \mathrm{D})$, otherwise the coating may detach. Due to the lack of correlation between welding cost and performance against abrasive wear, welding with greater hardness are not the more expensive. Although welding $2 \mathrm{D}$ has superior hardness in comparison to $1 \mathrm{~A}, 1 \mathrm{~B}, 1 \mathrm{C}$ and $1 \mathrm{D}$ hard coating (48.52 HRC), abrasive wear performance of 2D was slightly better. Maybe hard coating 2D could work against wear by impact or compression. The best abrasive wear performance and the greatest hardness were found for welding 4D, confirming the manufacturer's claims. Coating 3D had the secondbest performance; however, a couple of clarifications are necessary: welding $3 \mathrm{D}$ is more expensive than coating 4D, and since it has a Hadfield steel deposit, it is more advisable for cases of abrasion and impact rather than for only-abrasive-wear cases. Coatings $2 \mathrm{C}, 2 \mathrm{~B}, 2 \mathrm{~A}, 3 \mathrm{~A}$ and $4 \mathrm{~A}$ were ranked in third place of performance; the average values of wear resistance slightly varied among them, and their costs were lower in comparison to 3D and 4D. Finally, despite having the lowest cost, performance of hard coating $1 \mathrm{~A}$ was not the worst.

Variation in hardness was not correlated with volume loss, but it generally was a good indicator: the greater the hardness, the better the performance. Significant increase of abrasive wear resistance of steel was backed up by a decrease of volume loss down to two-thirds and increases of hardness up to 29 and 67 HRC. Selection of weld coating depends on the kind of application and failure mechanism (wear). For example, coatings that usually perform satisfactorily in working conditions that imply abrasive wear (due to their hardness) are not suitable for tasks involving wear by impact (due to their fragility). Regarding failure mechanisms, coatings with low contents of chromium and carbon fail due to plastic deformation, whereas coatings with high contents of such elements fail due to fragile decomposition of carbides [12].

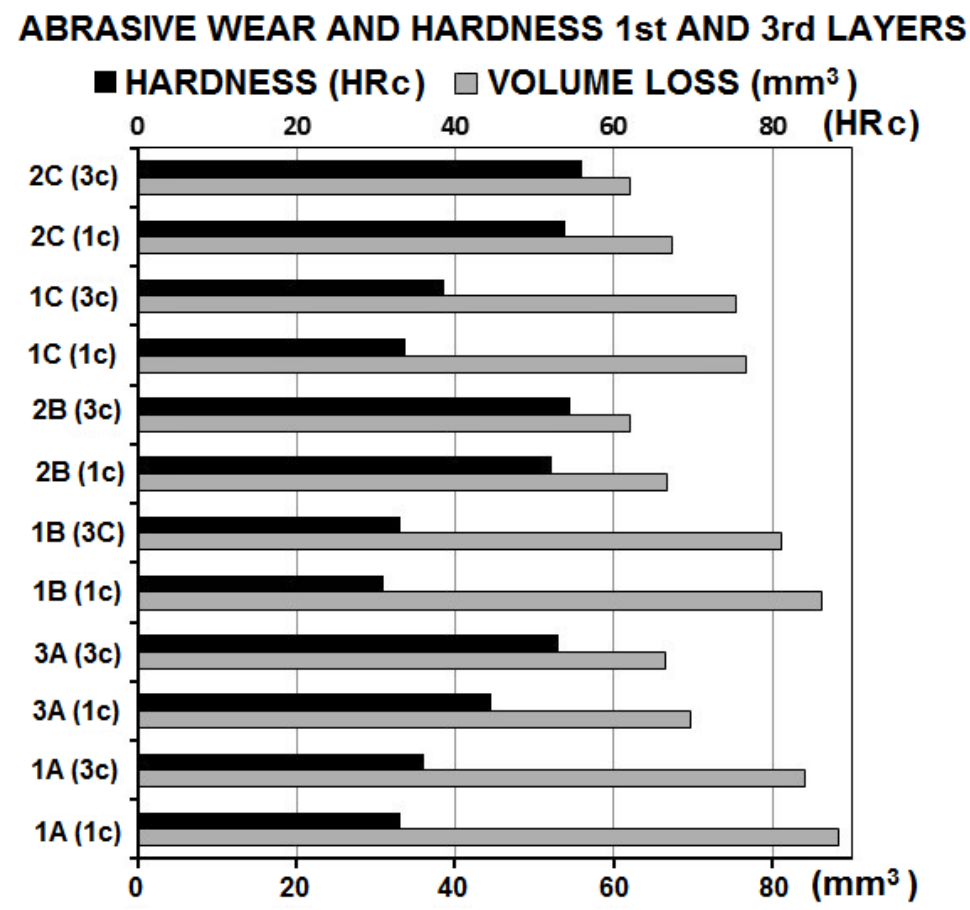

Fig. 2. Volume loss and hardness of coatings in the first and third layers. 
Scanning electron microscopy of the interphase metal base and hard coating 2B is illustrated in Figure 3. Micro-porosities, not detected by optical microscopy, were observed in both steel and filler metal. Punctual EDS analysis showed three zones: metal base (points 4 and 5), filler metal (points 1 and 2), and small dilution zone (point 3). Higher contents of chromium and silicon were reported for points 1 and 2, in comparison to metal base zone (6\% and $2 \%$ respectively). Such percentages allow the formation of chromium carbides, which are more abrasive wear resistant than iron carbides. EDS data corroborated the results shown in figures 1 and 2. Finally, silicon increase contributed to the emergence of morphologically more complex carbides [4].

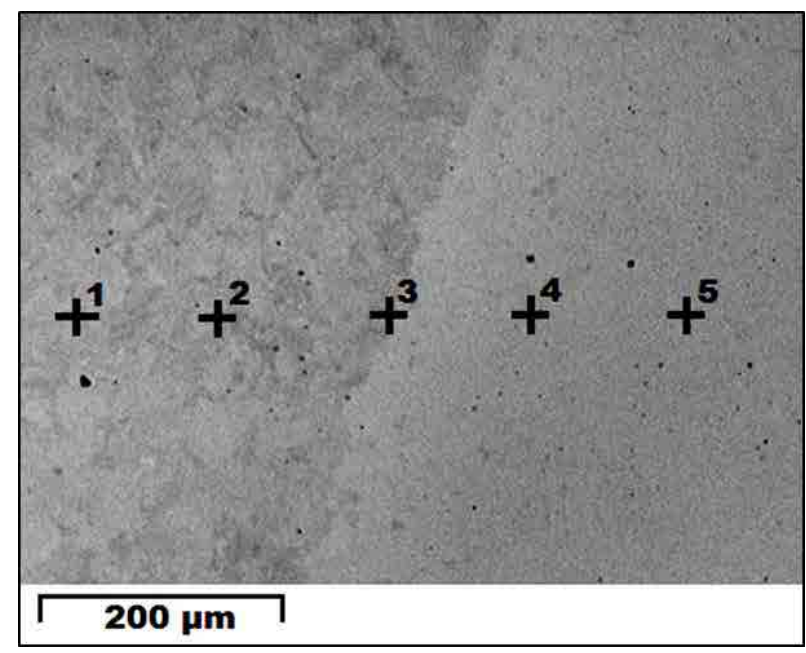

Fig. 3. Metal interface 2B hard coating and metal base AISI 1045.

Figure 4 depicts the SEM of nanostructured wear plates. These samples had the best anti-wear performance and the greatest hardness. The structure revealed a large amount of sub-micrometric carbides, uniformly distributed in the iron matrix with high content of chromium. Such homogeneity was achieved thanks to the accuracy of the welding procedure. EDS analysis confirmed the formation of matrices with low content of chromium and the following carbides for most wear plates tested herein: predominant presence of niobium carbides and minority presence of titanium and chromium carbides for nano plates; presence of molybdenum, titanium and chromium carbides for wear plates CDP 4666; presence of $\mathrm{Ti}, \mathrm{Cr}$, Mo and Co carbides for titanium wear plates, thus a good performance against severe abrasion and moderated impact is expected. In general, the existence of these carbides provides high hardness in ductile matrices and wear by impact resistance; therefore abrazo 400 and CR 400 wear plates are expected to perform well due to their porous structure with martensite and bainite mixture.

Unlike the iron matrices of uncoated wear plates, those of wear plates with coatings had high content of chromium with $\mathrm{Mo}, \mathrm{Ti}, \mathrm{Nb}$ and $\mathrm{Cr}$ carbides; this material exhibited the greatest hardness and the best performance against abrasive wear. The second place in performance corresponded to hard coatings applied by high hardness welding; since their iron matrices contained less chromium, hardness slightly decreased; furthermore, their resistance was also affected by the predominant production of iron carbides (which are less resistant than $\mathrm{Cr}$ carbides) and the absence of other kind of carbides. Wear plates with thermal treatment behaved less satisfactorily than hard coatings, due to the lack of production of complex carbides that improved their wear resistance. The worst performance corresponded to hard coatings with low wear resistance, which were the less expensive.

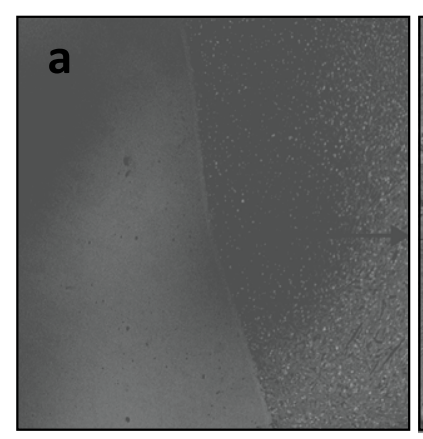

$200 \mu \mathrm{m}$

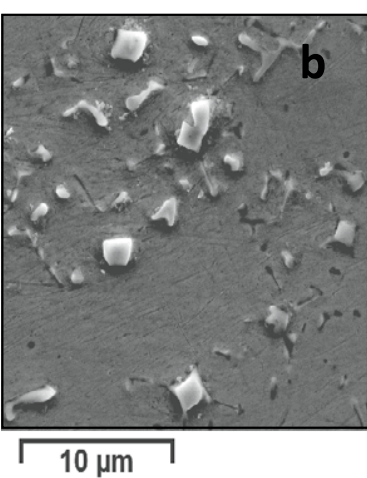

$10 \mu \mathrm{m}$
Fig. 4. Substrate-coating interface of nanostructured wear plates.

\section{Conclusions}

The results indicate a tendency of increasing abrasive wear resistance as hardness increases; however, a linear growth pattern was not observed due to the presence of factors such as weld deposit chemical composition, and shape and distribution of carbide, among others. Furthermore, increasing chromium in the weld deposit led to the formation of chromium carbides, which, in turn, exhibited greater wear resistance than iron carbides. 
Manufacturers' claims on technical data, chemical composition, main characteristics, and usage specifications and recommendations were confirmed. However, those claims were backed up by very unreliable wide value ranges. Therefore, comparative tables like the ones presented here may be useful tools and criteria for choosing between wear plates and hard coatings.

Even though the nanostructured wear plate did not have the greatest hardness, it exhibited the best abrasive wear resistance. Good anti-abrasive behavior was also found for wear plates CDP 4666 and CDP 6503. These three wear plates outperformed abrazo 400 and CR400. However, with the exception of hard coatings $4 \mathrm{D}$ and $3 \mathrm{D}$, the remaining hard coatings had inferior performance than abrazo 400 and CR400.

\section{REFERENCES}

[1] V. Jankauskas, et al. "Effect of WC grain size and content on low stress abrasive wear of manual arc welded hardfacings with low-carbon or stainless steel matrix," Wear, vol. 328-329, pp. 378-390, 2015. DOI: http://doi.org/10.1016/j.wear.2015.02.063.

[2] M. Woldman, et al. "Investigating the influence of sand particle properties on abrasive wear behavior," Wear, vol. 294-295, pp. 419-426, 2012. DOI: http:// doi.org/10.1016/j.wear.2012.07.017.

[3] T. Bremerstein, et al. "Wear of abrasive media and its effect on abrasive flow machining results," Wear, vol. 342-343, pp. 44-51, 2015. DOI: http://doi. org/10.1016/j.wear.2015.08.013

[4] W. Pérez, et al. "Desgaste abrasivo de cuchillas de arado rotativo en un suelo franco arenoso," Dyna, vol. 77 (162), pp. 105-114, 2010.
[5] R. Zahiri, et al. "Hardfacing using ferro-alloy powder mixtures by submerged arc welding," Surface \& Coatings Technology, vol. 260, pp. 220-229, 2014. DOI: http://doi.org/10.1016/j.surfcoat.2014.08.076.

[6] V. E. Buchanan, et al. "A comparison of the abrasive wear behaviour of iron-chromium based hardfaced coatings deposited by SMAW and electric arc spraying," Wear, vol. 264, pp. 542-549, 2008. DOI: http://doi.org/10.1016/j.wear.2007.04.008.

[7] K. Singh, et al., "Microstructure evolution and abrasive wear behavior of D2 steel," Wear, vol. 328-329, pp. 206-216, 2015. DOI: http://doi. org/10.1016/j.wear.2015.02.019.

[8] N. Ojala, et al. "Effects of composition and microstructure on the abrasive wear performance of quenched wear resistant steels," Wear, vol. 317, pp. 225-232, 2014. DOI: http://doi.org/10.1016/j. wear.2014.06.003.

[9] O.N. Cora, et al. "Die wear in stamping of advanced high strength steels - Investigations on the effects of substrate material and hard-coatings," Tribology International, vol. 52, pp. 50-60, 2012. DOI: http:// doi.org/10.1016/j.triboint.2012.02.016.

[10] S. Huang, et al., "Microstructures and properties of Ni based composite coatings prepared by plasma spray welding with mixed powders," Int. J. of Refractory Metals and Hard Materials, vol. 52, pp. 36-43, 2015. DOI: http://doi.org/10.1016/j.jirmhm.2015.05.011.

[11] J. L. Marulanda Arévalo, V. M. Burbano, J. A. Peláez, "Análisis de soldabilidad de aceros inoxidables con aceros de medio y bajo carbono por SMAW," Revista Facultad de Ingeniería, vol. 22 (35), pp. 91-100, 2013. DOI: http://doi.org/10.19053/01211129.2517.

[12] V. Jankauskas, et al. "Analysis of abrasive wear performance of arc welded hard layers," Wear, vol. 265, pp. 1626-1632, 2008. DOI: http://doi. org/10.1016/j.wear.2008.03.022. 